DOI https://doi.org/10.18551/rjoas.2018-04.30

\title{
PURCHASE DECISION OF CHEMICAL COMPOUND FERTILIZERS BY WHITE PEPPER FARMERS
}

\author{
Kusumah Echo Perdana*, Wahyudin Nanang \\ Faculty of Economics, University of Bangka Belitung, Indonesia \\ *E-mail: echo perdana@ubb.ac.id
}

\begin{abstract}
The purposes of this research are to analyze the influence of Brand Image, Promotion, and Distribution toward Purchase Decision of chemical compound fertilizer. The population in this research is White Pepper farmers in South Bangka Regency, Bangka Belitung Province, Indonesia. The sampling technique is a quota sampling method which results for 100 samples. The data analysis method uses descriptive statistical analysis and logistic regression analysis. The result of this study shows that several brands of chemical compound fertilizer that are preferred by white pepper farmers in South Bangka Regency are Yaramila, Wayang, and Phonska. Brand Image variable and Distribution variable influence on Purchase Decision. On the other hand, Promotion variable doesn't influence Purchase Decision.
\end{abstract}

\section{KEY WORDS}

Brand image, promotion, distribution, purchase decision, chemical compound fertilizers.

The growing economic condition of Indonesian society in the agricultural sector has resulted in the emergence of industries that seek to meet the needs of every farmer in the form of imported goods and domestic goods. As a result, the level of competition between similar industries becomes increasingly tight. Competition can be overcome if farmers as consumers can feel comfortable and can rely on a particular brand of agricultural products (Aaker, 2012). Judging from the increasingly widespread of similar industries, in this research is chemical fertilizer industry; they are trying to influence the farmers to buy their products. How producers in influencing consumers are one of them by doing promotion (Wierenga et al., 2012).

According to Kotler (2012), one form of promotion is advertising, in addition to other advertising media, namely personal selling, publicity, and sales promotion. Advertising is one of four essential tools that companies use to streamline effective communication toward purchases and targeted communities (Nava et al., 2013). Personal selling is the oral presentation in a conversation with one or more potential buyers to make a sale (Aaker \& Biel, 2013). Sales promotion is a short-term incentive to stimulate the purchase of a product or service. While publicity is spreading the important commercial news through the need for a particular product in a disseminated medium or generating an exciting presentation of the product on the radio, television or stage not paid by the sponsor (Moriarty et al., 2014). Advertising conducted by the company can be done through media magazines, radio, television, and billboards. The selection of advertising media done by the company is usually tailored to the needs of the company. Understanding the advertisement by Hollensen (2010) is all forms of non-personal presentation of promotional ideas, promotions of goods or services performed by certainly paid sponsors. In addition to advertisements, brands are among the factors that can influence purchasing decisions. The promotion of chemical fertilizers in the islands of Bangka Belitung province according to the author's observation is not very interesting. The promotion is dominant only using the method words of mouth without any significant promotional efforts on print and electronic media.

According to Aaker (2012), a good brand image is to provide good quality products for consumers. Successful brands have great potential to generate even more profits if the company can aggressively and persistently brand them through various ways such as brand extensions or line extensions. For many businesses, the brand name and what it contains is 
the cornerstone of the strategy of leaf, and the source of future income (Aaker \& Joachimsthaler, 2012). For the company, the brand can become more valuable, because it can use it to build a consumer confidence base in determining the choice of a product (Kapferer, 2012). No matter how good a product is, if the consumer has never heard it and is not convinced that it will be of use to them, they will never buy it. So that the brand of a product widely known by the consumer then it is necessary if the seller to do other marketing activities of promotion. Promotion is a flow of information or one-way persuasion made to direct a person or organization to actions that create exchanges in marketing (Hartley \& Claycomb, 2013). Such marketing exchange can be realized if there is a product offered; the product can be traded through the distribution process. The behaviour of farmers in the island province of Bangka Belitung on the purchase of fertilizer tends to believe that the brand of fertilizer used by his ancestors is better than trying another brand of fertilizer.

Armstrong et al., (2015), implicitly states that distribution is a marketing activity that seeks to smoothen and facilitate the delivery of goods and services from producers to consumers so that its use in accordance with the required (type, amount, price, place, and when needed). This distribution role is very important for white pepper farmers in the Bangka Belitung Islands Province. Without a good distribution, will lead to a decrease in production, due to fertilizer delays. The geographic condition of the Bangka Belitung Islands Province which is an archipelago area and has no chemical fertilizer company makes the distribution process very vital. Distribution of chemical fertilizers conducted by fertilizer companies outside the province of Bangka Belitung Islands, such as Pusri, Petrokimia, Yaramila, etc.

The results of previous research that support is research conducted by Bian \& Moutinho (2011); Nigam, \& Kaushi (2011); Wang \& Yang (2010); Malik et al., (2013); Shah et al., (2012); Malik et al., (2013); Prendergast et al., (2010), which states the existence of a significant positive influence between brand image, promotion and distribution variables on consumer purchasing decisions. Based on the description above shows that brand image, promotion and distribution is an important factor in determining consumer purchasing decisions. Therefore, the authors are interested to do research about the influence of brand image, promotion, and distribution on purchasing decision chemical fertilizer by white pepper farmers in the province of Bangka Belitung islands, Indonesia.

The hypothesis in this research is as follows:

$\mathrm{H} 1$ : Brand Image has a positive and significant influence on purchase decision.

$\mathrm{H} 2$ : Promotion has a positive and significant influence on decision purchase.

H3: Distribution has a positive and significant influence on purchase decision.

H4: Brand Image, Promotion, and Distribution together have positive and significant influence on purchase decision.

\section{METHODS OF RESEARCH}

This study uses a quantitative approach. According to Babbie (2010), quantitative methods emphasize objective measurements and the statistical, mathematical, or numerical analysis of data collected through polls, questionnaires, and surveys, or by manipulating preexisting statistical data using computational techniques. Quantitative research focuses on gathering numerical data and generalizing it across groups of people or explaining a particular phenomenon (Mujis, 2010). Data collection through research instruments in the form of questionnaires, data analysis is statistical or quantitative aims to test the hypothesis. Interview method is also conducted by researchers to find out the chemical fertilizer brand that the farmers are interested in cultivating white pepper plant. The place of this research was conducted in Bangka Belitung Province, Indonesia. Bangka Belitung Province is famous as one of the world's white pepper commodities producer named Muntok White Pepper (International Pepper Community).

The number of samples determined by the researchers is 100 white pepper farmers spread in South Bangka Regency. The number of samples to be used in this study is determined by using quota sampling technique. Quota sampling method is a non-probability sampling, and it can be defined as a sampling method of gathering representative data from 
a group (Saunders, Lewis, \& Thornhill, A, 2012). Application of quota sampling ensures that sample group represents particular characteristics of the population chosen by the researcher (Saunders, Lewis, \& Thornhill, 2012).

Analytical tool used in this research is descriptive statistic analysis and logistic regression analysis (logistic regression) using the SPSS application version 25. The SPSS application is easy to use and useful in processing quantitative data (Kusumah, 2018). Descriptive statistics are statistics that serve to describe or gives an overview of the object under study through sample data or population as it is, without doing any data analysis makes that conclusion applies to the public (Sugiyono, 2016). Meanwhile, the reason for the use of logistic regression is that the dependent variable is dichotomous (performs a hub and does not make a change hood). Ghozali (2016) states that the logistic regression method is similar to the discriminant analysis. This analysis wants to test whether the profitability of dependent variables can be predicted with independent variables. According to Ghozali (2016), the use of regression method does not require the assumption of normality on the independent variables. Normal multivariate distribution assumptions cannot be met because the independent variables are a mixture of continuous (metric) and categorical (non-metric). In this case, can be analyzed by logistic regression (logistic regression) because it is not a necessary assumption of data normality on the independent variable. Stages of testing by using logistic regression test (logistic regression) can be explained as follows:

Testing Research Hypotheses.

Estimated parameters using Maximum Likelihood Estimation (MLE):

$$
\begin{aligned}
& \mathrm{Ho}=\mathrm{b} 1=\mathrm{b} 2=\mathrm{b} 3=\ldots=\mathrm{bi}=0 \\
& \mathrm{Ho} \_\mathrm{b} 1 \_\mathrm{b} 2 \_\mathrm{b} 3 \_\ldots \text { _ }
\end{aligned}
$$

The null hypothesis states that the independent variable has no effect on the response variable (in the population). Hypothesis testing is done by using $\alpha=5 \%$. The rules of decision-making are:

a) If the probability value (sig.) $<\alpha=5 \%$ then the alternative hypothesis is supported.

b) If the probability value (sig.) $>\alpha=5 \%$ then the alternative hypothesis is not supported.

Model Fit:

The first step is to assess the overall fit model of the data. Some statistical tests are given to assess this. The hypothesis for assessing the fit model is:

$\mathrm{H}_{0}$ : The hypothesized fit model with the data

$\mathrm{H}_{1}$ : The hypothesized model is not fit with the data

From this hypothesis, it is clear that we will not reject the null hypothesis to fit the model with the data. The statistics used are based on the likelihood function. The Likelihood $L$ of the model is the probability that the hypothesized model represents the input data. To test the null and alternative hypothesis, $L$ is transformed to -2LogL. A decrease in likelihood $(-2 L L)$ indicates a better regression model or in other words a hypothesized fit model with data.

The coefficient of Determination (Nagelkerke R Square):

Cox and Snell's $R$ Square are measured attempting to replicate the $2 \mathrm{R}$ size in multiple regression based on likelihood estimation techniques with a maximum value of less than 1 (one) making it difficult to interpret. Nagelkerke's R square is a modification of Cox and Snell coefficients to ensure that its value varies from 0 (zero) to 1 (one). That is done by dividing the Cox and Snell's R Square values with their maximum values. Nagelkerke's R Square values can be interpreted as $R$ Square values in multiple regression. A small value means the ability of independent variables to explain the variation of the dependent variable is insufficient. A value close to one means independent variables provide almost all the information needed to predict the variability of a dependent variable.

Testing the Regression Model Eligibility:

The feasibility of the regression model was assessed using Hosmer and Lemeshow's Goodness of Fit Test. The Hosmer and Lemeshow's Goodness of Fit Test tests the null 
hypothesis that empirical data matches or fits the model (there is no difference between the model and the data so that the model is fit). If the value of Hosmer and Lemeshow's Goodness of Fit Test statistics is equal to or less than 0.05 , then the null hypothesis is rejected which means there is a significant difference between the model and the observed value so that the Goodness fit model is not good because the model cannot predict the observed value. If the statistical value of Hosmer and Lemeshow's Goodness of Fit Test is greater than 0.05 , then the null hypothesis cannot be rejected and means the model can predict the observed value or it can be said that the model is acceptable because it matches the observation data.

Logistic Regression Model:

The analysis used in this research is logistic regression analysis. Namely by looking at the effect of the brand image, promotion, distribution to purchasing decision. Logistic regression model in this research is as follows:

$$
P D=\beta o+\beta_{1} B I+\beta_{2} P+\beta_{3} D+e
$$

Where:

$$
\begin{aligned}
& P D=\text { Purchase Decision } \\
& \beta O=\text { Constant } \\
& \beta_{1}-\beta_{3}=\text { Regression coefficients } \\
& \mathrm{BI}=\text { Brand Image }
\end{aligned}
$$

$$
\begin{aligned}
& P=\text { Promotion } \\
& D=\text { Distribution } \\
& e=\text { Error }
\end{aligned}
$$

\section{RESULTS OF STUDY}

This descriptive statistic is a statistical test used to find out the general description of chemical fertilizer brand selection by white pepper farmers in South Bangka Regency. The following statistic descriptive test results can be seen in the attachment and briefly shown in the following figure:

\section{Brand of chemical fertilizer known to farmers in South Bangka Regency}

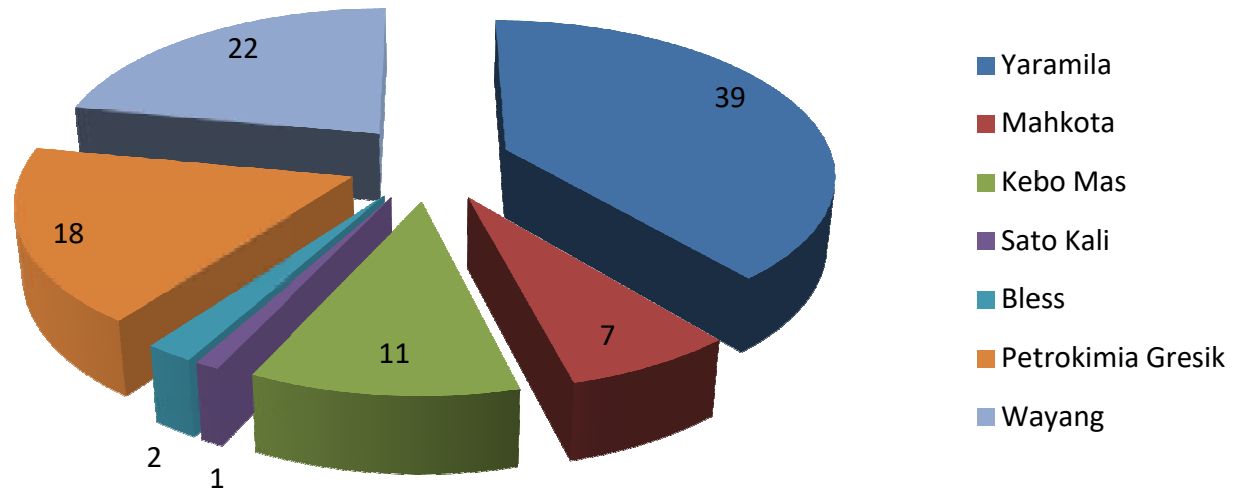

Figure 1 - Descriptive analysis

Based on the data above, it can be known that chemical fertilizer brands in the form of compound fertilizer which is often used by farmers in South Bangka Regency are: Yaramila $(39 \%)$, Wayang (22\%), Petrokimia Gresik (18\%), Kebo Mas (11\%), Mahkota (7\%), Bless $(2 \%)$, and Sato Kali (1\%).

Based on observations of researchers, compound fertilizer is widely dispersed and sold in South Bangka Regency. In particular, Yaramila-branded compound fertilizer is a favourite of white pepper farmers in the district. Yaramila compound fertilizer is considered by many 
white pepper farmers as fertilizer that must be used in the cultivation of white pepper. According to the testimony of the farmers, the nature of the fertilizer is more quickly absorbed by white pepper plant. While the other popular compound fertilizer among farmers is a compound fertilizer branded Wayang. The fertilizer, according to white pepper farmers, has a better quality compared to Yaramila-branded compound fertilizer for white pepper, but the price is higher than the Yaramila-branded compound fertilizer. Compound fertilizer branded Petrokimia Gresik or known as Phonska is an alternative option of white pepper farmers in South Bangka Regency, because the fertilizer is a government subsidy fertilizer with a balanced element. The white pepper farmers choose the fertilizer subsidy because the price is relatively lower than the compound fertilizer above. Phonska compound fertilizer is relatively cheaper because of government subsidies, but the amount of compound fertilizer available is not enough to meet the needs of white pepper farmers in South Bangka Regency.

Parameter Estimation and Interpretation (Hypothesis):

Table 1 - Significant Test of Data

\begin{tabular}{|c|c|c|c|c|}
\hline- & B & S.E. & Wald & Sig. \\
\hline $\mathrm{BI}$ & 1.388 & .692 & 4.027 & .045 \\
\hline $\mathrm{P}$ & .248 & .811 & .094 & .759 \\
\hline $\mathrm{D}$ & 1.975 & .855 & 5.337 & .021 \\
\hline Constant & -2.544 & .468 & 29.583 & .000 \\
\hline
\end{tabular}

Source: Data processed by researchers, 2018.

Based on table 1 above shows that the coefficient of Brand Image $(\mathrm{BI})$ variable is significant, Promotion $(P)$ is not significant and Distribution $(D)$ is significant. That shows the results of hypothesis testing can be explained as follows: a). Brand Image (BI) variable has positive regression coefficient value of 1,388 with significant value level of $0.045<\alpha=0.05$ (significantly smaller than 0.05 ) then Brand Image $(\mathrm{BI})$ variable is significant, so hypothesis 1 is accepted. b). Promotion $(P)$ has a positive regression coefficient value of 0.248 with a significant value level of $0.759>\alpha=0.05$ (significantly greater than 0.05 ) then the Promotion $(P)$ variable is insignificant, so hypothesis 2 is rejected. c). Variable Distribution (D) has a positive regression coefficient value of 1.975 with a significant value level of $0.021<\alpha=0.05$ (significantly smaller than 0.05 ) then the Distribution (D) variable is significant, so hypothesis 3 is accepted.

Model Total Test (Overall Model Fit):

This test is performed to assess the model that is hypothesized to fit the data or not. Testing is done by comparing the value between -2 log likelihood at the beginning with the value computed. Thus the decrease in log likelihood shows a better regression model, as shown in the following table:

Table 2 - Overall Model Accuracy Test

\begin{tabular}{|c|c|c|c|c|c|c|}
\hline & & $-2 \log$ & & \multicolumn{3}{|c|}{ Coefficients } \\
\hline Iteration & & likelihood & Constant & $\mathrm{BI}$ & $\mathrm{P}$ & D \\
\hline \multirow[t]{4}{*}{ Step 0} & 1 & 116.763 & -.920 & & & \\
\hline & 2 & 116.652 & -.993 & & & \\
\hline & 3 & 116.652 & -.995 & & & \\
\hline & 4 & 116.652 & -.995 & & & \\
\hline \multirow[t]{5}{*}{ Step 1} & 1 & 81.324 & -1.744 & 1.040 & .138 & 1.468 \\
\hline & 2 & 77.728 & -2.359 & 1.322 & .220 & 1.858 \\
\hline & 3 & 77.558 & -2.532 & 1.384 & .246 & 1.967 \\
\hline & 4 & 77.557 & -2.544 & 1.388 & .248 & 1.975 \\
\hline & 5 & 77.557 & -2.544 & 1.388 & .248 & 1.975 \\
\hline
\end{tabular}

Source: Data processed by researchers, 2018.

Based on the calculation of this analysis yield -2log likelihood value of 116.652 seen in iteration history at step 0 (block number $=0$ ). The calculation result of likelihood -2 log value 
in the second block (block number $=1$ ) or at step 1 it shows that -2 log likelihood equal to 77.557. That indicates a decrease in the likelihood -2log value in the second block (block number $=1$ ) because at the value of -2 log likelihood block number $0>$ value -2 log likelihood block number 1 (116.652 - 77.557). The overall assessment of the regression model uses the likelihood -2log value where if there is a decrease in the second block than the first block it can be concluded that the second regression model is better. The decrease in the value of log-2 likelihood block number 0 - value -2log likelihood block number 1 (116.652 - 77.557) is 39.095 with a significance level of 0.000 based on the analysis of omnibus tests of model coefficients, so it shows that the model has hypothesized accordingly (fit model) with data. For more can be explained as shown in the following table:

Table 3 - Omnibus Tests

\begin{tabular}{lcccc}
\hline \multirow{2}{*}{ Step 1} & & Chi-square & df & Sig. \\
& Step & 39.095 & 3 & 0.000 \\
& Block & 39.095 & 3 & 0.000 \\
& Model & 39.095 & 3 & 0.000 \\
\hline
\end{tabular}

Source: Data processed by researchers, 2018.

The results of the test table above show the value of chi-square of 39,095 with a significant level of less than 0.05 (0.000). So that independent variable of Brand Image, Promotion, and Distribution are said to have a simultaneous influence on the dependent variable Purchase Decision (hypothesis 4 is accepted).

Determination Coefficient Test (Nagelkerke R Square):

Testing the coefficient of determination on logistic regression is done by using Nigelkerke's R Square. The purpose of the summary model is to find out how large combinations of independent variables can explain variations of dependent variables, as shown in the following table:

Table 4 - Determination Coefficient Test

\begin{tabular}{cccc}
\hline Step & -2 Log likelihood & Cox \& Snell R Square & Nagelkerke R Square \\
1 & $77.557^{\mathrm{a}}$ & 0.324 & 0.470 \\
\hline
\end{tabular}

Source: Data processed by researchers, 2018.

The value of Nagelkerke R Square of 0.470 shows the variability of Purchase Decision is explained by Brand Image, Promotion, and Distribution variables, by $47 \%$, the remaining $53 \%$ is explained by other variables outside the research model.

Feasibility Test of the Regression Model (Goodness of Fit Test):

The feasibility of the regression model is determined based on the value of Hosmer \& Lemeshow's goodness of fit test. Testing goodness of fittest is measured by Chi-square value at the bottom of Hosmer and Lemeshow test. The following is the result of identification of classification prediction in the following table:

Table 5 - Goodness of Fit

\begin{tabular}{ccccc}
\hline Step & Chi-square & df & Sig. & \\
1 & 1.039 & 3 & 0.792 & \\
\hline
\end{tabular}

Source: Data processed by researchers, 2018.

Test results in the above table show the value of chi-square of 1.039 with a significant value of 0.792 . From these results it can be seen that significant value $>\alpha=0.05$ (significant above 0.05) means that the decision taken is accepted, there is no difference between the classification predicted by the observed classification. It shows that the model can predict the observed value or the model is acceptable because it matches the observation data so that the model is suitable (fit model) and can be used for further analysis.

Logistic Regression Model: 
Logistic regression model in this research is to test the influence of Brand Image (BI), Promotion (P), and Distribution (D) toward Purchase Decision (PD). To see the significant results of each coefficient in this logistic regression, we use an equation model that includes all the independent variables shown in the following table:

Table 6 - Significant Test of Logistic Regression Model

\begin{tabular}{cccccc}
\hline & B & S.E. & Wald & Sig. & Exp(B) \\
BI & 1.388 & .692 & 4.027 & .045 & 4.007 \\
P & .248 & .811 & .094 & .759 & 1.282 \\
D & 1.975 & .855 & 5.337 & .021 & 7.204 \\
Constant & -2.544 & .468 & 29.583 & .000 & 0.079 \\
\hline
\end{tabular}

Source: Data processed by researchers, 2018.

The regression equation formed from the significance test of the data is as follows:

$$
\text { Purchase Decision }(P D)=-2.544+1.388 \mathrm{BI}+0.248 \mathrm{P}+1.975 \mathrm{D}+\mathrm{e}
$$

Interpretation of Equations:

- For every increase in the Brand Image variable, it will increase Purchase Decision by 1.388.

- For each increase in the Promotion variable of 1 unit, it will increase Purchase Decision by 0.248 .

- From the value of significance, we can conclude that the significant variables affect the Purchase Decision is Brand Image $(\mathrm{BI})$ and Distribution $(\mathrm{D})$ with the significance value of 0.045 and 0.021 (95\% significance level).

- The amount of influence can also be indicated by the value of $\operatorname{Exp}(B)$ or also called Odds Ratio (OR). Interpretation of $\operatorname{Exp}(B)$

- Brand Image variables tend to increase Purchase Decision of 4.007 times with a good significance value of $0.045<0.05$.

- Promotion variables tend to increase Purchase Decision of 1.282 times with unmatched significance value of $0.759>0.05$.

- Distribution variables tend to increase Purchase Decision of 7.204 times with a good significance value of $0.021<0.05$.

The results of the first hypothesis testing showed that Brand Image variables have a significance level of $0.045<\alpha=0.05(5 \%)$, then Brand Image variables have an influence on Purchase Decision. The reason is that brand image (brand image) is often used as an external requirement to make a purchase decision (Pulizzi, 2014). If consumers do not have experience with a product, they tend to trust a brand that is popular or famous (Sheth \& Sisodia, 2015). A brand that has a positive or favoured image is considered to reduce the risk of purchase (Keller \& Kotler, 2016). That is why consumers often use the brand image of a product as a reference in making a purchase decision.

The result of the second hypothesis test shows that Promotion variable has the significance level of $0.759>\alpha=0.05(5 \%)$, then Promotion variable does not influence Purchase Decision. The reason is the lack of promotion by the chemical fertilizer company. Promotions by the chemical fertilizer company that exists today only rely on word of mouth from the existing distributor of fertilizer in South Bangka Regency without any other promotion. Promotions like this make purchasing decisions on the part of white pepper farmers to be uncertain.

The result of the third hypothesis testing shows that the Distribution variable has a significance level of $0.004<\alpha=0.05(5 \%)$, then the Distribution variable has an influence on the Purchase Decision. The reason is the distribution of chemical fertilizers in South Bangka Regency is sufficient; it can be seen from the observations of researchers who see that chemical fertilizers are available in large farm shops to retail shops located in every village in South Bangka Regency. The distribution channel is a result of the synergy that builds between the company's capabilities and the company's resources and expertise that is 
rooted in the concept of product marketing success. Intensive distribution suppresses the length of time customers find stores, providing a convenient place to make purchases and make it easier to get product-related services (Harker et al., 2015). As the intensity of distribution increases, customers have time and place to know the value of a product (Kotler \& Kotler, 2012). The increased value of the product, most of it is contributed to the reduction in the sacrifices that customers make to obtain the product (Chattopadhyay et al., 2012). Such value increases will increase the likelihood of customers making a purchase decision.

\section{CONCLUSION AND SUGGESTIONS}

This research was conducted to observe the influence of Brand Image, Promotion, and Distribution on Purchasing Decision of chemical compound fertilizer of white pepper farmers in South Bangka Regency, Bangka Belitung Islands Province, Indonesia. Based on the results of the analysis can be summarized as follows: 1). Brand Image partially influence the Purchase Decision with a significance level of $0.045<0.05$. Therefore, the first hypothesis is accepted. 2) Promotion has no partial effect on Purchase Decision with significance level of $0.759>0.05$. Therefore the second hypothesis is rejected. 3). Distribution partially influence the Purchase Decision with a significance level of $0.021<0.05$. Hence the third hypothesis is accepted. 4). Brand Image, Promotion, and Distribution have an effect simultaneously on Purchase Decision with significance level 0.000. Therefore, the fourth hypothesis is accepted.

Based on the limitations and weaknesses that exist in this study, it can be suggested some suggestions that can be considered for further research, namely: 1) The next object of research not only use the white pepper farmers but also can increase the other commodity as well as with the number of more samples so that the research can be more generalized. 2) Researchers further suggested adding another variable that is suspected to influence the purchase decision.

\section{REFERENCES}

1. Aaker, D. A. (2012). Building strong brands. Simon and Schuster.

2. Aaker, D. A., \& Biel, A. L. (2013). Brand equity \& advertising: advertising's role in building strong brands. Psychology Press.

3. Aaker, D. A., \& Joachimsthaler, E. (2012). Brand leadership. Simon and Schuster.

4. Armstrong, G., Kotler, P., Harker, M., \& Brennan, R. (2015). Marketing: an introduction. Pearson Education.

5. Bian, X., \& Moutinho, L. (2011). The role of brand image, product involvement, and knowledge in explaining consumer purchase behaviour of counterfeits: Direct and indirect effects. European Journal of Marketing, 45(1/2), 191-216.

6. Chattopadhyay, A., Batra, R., \& Ozsomer, A. (2012). The new emerging market multinationals: Four strategies for disrupting markets and building brands. McGraw Hill Professional.

7. Ghozali, I. (2016). Aplikasi Analisis Multivariate Dengan Program IBM SPSS 23. Semarang: Badan Penerbit Universitas Diponegoro.

8. Harker, M., Brennan, R., Kotler, P., \& Armstrong, G. (2015). Marketing: An Introduction. Pearson Prentice-Hall, London.

9. Hartley, R. F., \& Claycomb, C. (2013). Marketing mistakes and successes. Wiley.

10. Hollensen, S. (2010). Marketing management: A relationship approach. Pearson Education.

11. International Pepper Community. (n.d.). Pepper in Indonesia. Retrieved January 07, 2018, from http://www.ipcnet.org/n/map/?path=map\&page=id

12. Kapferer, J. N. (2012). The new strategic brand management: Advanced insights and strategic thinking. Kogan page publishers.

13. Keller, K. L., \& Kotler, P. (2016). Marketing management. Pearson.

14. Kotler, P. (2012). Kotler on marketing. Simon and Schuster. 
15. Kotler, P., \& Kotler, M. (2012). Market your way to growth: 8 ways to win. John Wiley \& Sons.

16. Kusumah, E. P. (2018). Technology Acceptance Model (TAM) of Statistical Package for the Social Sciences (SPSS) Applications. Integrated Journal of Business and Economics,

17. 2(1), 1-11.

18. Malik, M. E., Ghafoor, M. M., Iqbal, H. K., Ali, Q., Hunbal, H., Noman, M., \& Ahmad, B. (2013). Impact of brand image and advertisement on consumer buying behavior. World Applied Sciences Journal, 23(1), 117-122.

19. Malik, M. E., Ghafoor, M. M., Hafiz, K. I., Riaz, U., Hassan, N. U., Mustafa, M., \& Shahbaz, S. (2013). Importance of brand awareness and brand loyalty in assessing purchase intentions of consumer. International Journal of Business and Social Science, 4(5).

20. Moriarty, S., Mitchell, N. D., Wells, W. D., Crawford, R., Brennan, L., \& Spence-Stone, R. (2014). Advertising: Principles and practice. Pearson Australia.

21. Muijs, D. (2010). Doing Quantitative Research in Education with SPSS. 2nd edition. London: SAGE Publications.

22. Nava, M., Blake, A., MacRury, I., \& Richards, B. (2013). Buy this book: studies in advertising and consumption. Routledge.

23. Nigam, A. (2011). Impact of brand equity on customer purchase decisions: an empirical investigation with special reference to hatchback car owners in central haryana. International Journal of Computational Engineering \& Management, 12, 121-128.

24. Prendergast, G. P., Tsang, A. S., \& Chan, C. N. (2010). The interactive influence of country of origin of brand and product involvement on purchase intention. Journal of Consumer Marketing, 27(2), 180-188.

25. Pulizzi, J. (2014). Epic content marketing: How to tell a different story, break through the clutter, and win more customers by marketing less (p. 5). McGraw-Hill Education.

26. Saunders, M., Lewis, P. \& Thornhill, A. (2012). Research Methods for Business Students.

27. 6th edition. Pearson Education Limited.

28. Shah, S. S. H., Aziz, J., Jaffari, A. R., Waris, S., Ejaz, W., Fatima, M., \& Sherazi, S. K. (2012). The impact of brands on consumer purchase intentions. Asian Journal of Business Management, 4(2), 105-110.

29. Sheth, J. N., \& Sisodia, R. S. (2015). Does marketing need reform?: Fresh perspectives on the future. Routledge.

30. Sugiyono. (2016). Metodologi Penelitian Kuantitatif, Kualitatif, dan R\&D. Bandung: CV Alfabeta.

31. Wang, X., \& Yang, Z. (2010). The effect of brand credibility on consumers' brand purchase intention in emerging economies: The moderating role of brand awareness and brand image. Journal of Global Marketing, 23(3), 177-188.

32. Wierenga, B., van Tilburg, A., Grunert, K. G., Steenkamp, J. B. E., \& Wedel, M. (Eds.). (2012). Agricultural marketing and consumer behavior in a changing world. Springer Science \& Business Media. 